\title{
Karakteristik Modal Sosial pada Kelompok Pengrajin Batik Kota Semarang
}

\author{
Characteristics of Social Capital on Batik Craftperson Group \\ in Semarang City
}

Yoshe Rezky A.M.Putri ${ }^{1}$, Prihadi Nugroho²

Diterima: 28 Maret 2018 Disetujui: 17 Agustus 2018

\begin{abstract}
Abstrak: Batik menjadi salah satu Industri Kecil Menengah (IKM) yang sedang dikembangkan di Kota Semarang. Namun, faktor lokasi menjadi kelemahan industri batik Kota Semarang. Lokasi pengrajin yang menyebar mengakibatkan kurangnya perhatian masyarakat terkait keberadaan batik Semarang. Oleh karena itu, FEDEP (Forum Economic Development and Employement Promotion) Kota Semarang telah membentuk kelompok pengrajin batik di Kota Semarang sejak tahun 2006. Keberadaan kelompok ini memicu tumbuhnya modal sosial antarpengrajin, sehingga dapat berinteraksi dan bekerja sama dalam meningkatkan produktivitas usaha. Penelitian ini bertujuan untuk menjelaskan bagaimana karakteristik modal sosial yang dimiliki oleh kelompok pengrajin batik Kota Semarang. Metode yang digunakan yaitu sequentials mix method dengan unit data sebanyak 31 anggota kelompok pengrajin batik di Kota Semarang. Rasa percaya (trust), norma (norm), dan jejaring (network) memiliki karakteristik masing-masing untuk memperkuat, mempererat, dan meningkatkan kebersamaan pengrajin dalam mengembangkan usaha. Ketiga komponen modal sosial ini juga berperan dalam manajemen kelompok untuk membentuk strategi pengembangan, alokasi dana, kerja sama, dan kegiatan kelompok. Melalui karakteristik modal sosial yang dimiliki oleh kelompok pengrajin batik Kota Semarang diharapkan mampu membuktikan bahwa perkembangan IKM tidak selalu terfokus pada lokasi, melainkan karakteristik modal sosial pelaku usaha yang terbentuk.
\end{abstract}

Kata kunci: Industri Kecil Menengah, Kelompok Pengrajin Batik, Modal Sosial

Abstract: Batik is one of many small and medium enterprises (SMEs) which is being developed in Semarang City. However, location becomes the weakness of the batik industry in Semarang City. The scattered location of batik craftpersons makes public did not concern to the existence of batik Semarang. Therefore, FEDEP (Forum Economic Development and Employement Promotion) of Semarang City has formed a Semarang's Batik Craftperson Group since 2006. The existence of this group has triggered the social capital among the craftperson, so they can interact and cooperate to improve their business productivity. This study aims to explain how the characteristics of social capital on Batik Craftperson Group in Semarang City. The method used sequential mix method with data unit is 31 members of Semarang's Batik Craftperson Group. Trust, norms, and networks have their own characteristics to improve the business through interactions and communications. These

${ }^{1}$ Kementerian Agraria dan Tata Ruang/Badan Pertanahan Nasional Republik Indonesia

2 Departemen Perencanaan Wilayah dan Kota, Universitas Diponegoro

Korespondensi: yoshe.rezky17@pwk.undip.ac.id 
three components also play a role in group management to make strategies, allocations, cooperations, and group activities. The characteristics of social capital on Batik Craftperson Group is expected to prove that so many factors that can develop SMEs, not only location but also the social capital of its business actors.

Keywords: Small and Medium Enterprises, Batik Craftperson Group, Social Capital

\section{PENDAHULUAN}

Industri menjadi salah satu aktivitas utama di Kota Semarang. Perkembangan industri mengacu pada isu strategis Rencana Pembangunan Jangka Menengah Daerah (RPJMD) Kota Semarang tahun 2016 - 2021 terkat peningkatan ekonomi dan daya saing daerah. Tahun 2010 Kota Semarang memiliki 377 unit industri besar dan sedang, serta 64 sentra industri kecil (BPS, 2010). Berdasarkan data tersebut, dapat diketahui bahwa industri mampu menyerap kurang lebih 100 ribu tenaga kerja. Keberadaan industri tersebut menggambarkan adanya peluang bagi masyarakat untuk bekerja, khususnya melalui industri kecil dan menengah (IKM).

Industri kecil dan menengah (IKM) merupakan salah satu pendekatan Pemerintah Daerah untuk mempercepat perekonomian. Bentukan sentra dan klaster industri menjadi salah satu program ekonomi untuk memberdayakan IKM. Namun, pengembangan konsep klaster di Kota Semarang tampak tidak sejalan dengan teori yang dijelaskan oleh beberapa peneliti terdahulu. Marshall (1920) awalnya mendefinisikan konsep sentra industri dalam tulisannya yang berjudul Marshallian Industrial District. Konsep tersebut mendefinisikan sentra industri sebagai IKM yang terhubung dalam satu wilayah dengan hubungan bisnis yang kuat secara internal. Klaster industri diartikan sebagai sekumpulan industri yang berada dalam satu wilayah berdekatan serta membentuk ikatan atau jejaring untuk berinteraksi dan bekerja sama dalam meningkatkan usaha (Porter, 1985). Pemahaman mengenai klaster industri juga dapat disimpulkan menjadi tiga unsur utama (Lyon \& Atherton, 2000), antara lain kesamaan (commonality), terkonsentrasi (concentration), dan terkoneksi (connectivity).

Salah satu IKM yang menjadi fokus pembangunan adalah IKM batik. FEDEP (Forum Economic Development and Employement Promotion) Kota Semarang telah membentuk kelompok pengrajin batik yang juga disebut sebagai klaster industri batik di Kota Semarang sejak tahun 2006. Anggota yang tergabung dalam kelompok ini juga tidak teraglomerasi sehingga tidak memiliki salah satu unsur concentration sebagaimana yang terkandung dalam definisi klaster secara teoritis. Hal ini menjadi sebuah evaluasi bagi Kota Semarang dalam mengembangkan konsep klaster tersebut. Meskipun demikian, kelompok pengrajin batik memiliki manajemen organisasi yang hampir mirip dengan klaster untuk mengembangkan produktivitas usaha dari masing-masing pengrajin.

Djamhari (2006) menyebutkan bahwa daya hidup kelompok industri dipengaruhi oleh inovasi teknologi, modal sumber daya manusia dan kewirausahaan, infrastruktur fisik, keberadaan perusahaan besar, akses ke pembiayaan usaha, layanan jasa spesialis, akses terhadap pasar dan informasi pasar, akses terhadap pendukung bisnis, persaingan, komunikasi, kepemimpinan, serta jejaring kemitraan. Jejaring kemitraan ini dapat dibentuk melalui modal sosial antarpengrajin yang tergabung dan terlibat di dalam organisasi kelompok pengrajin batik Kota Semarang.

Kelompok pengrajin batik Kota Semarang saat ini memiliki 31 anggota aktif dari 39 anggota yang terdaftar. Aktivitas produksi meliputi aktivitas input, proses, output, distribusi, dan pemasaran. Modal sosial yang terkandung di dalam keanggotaan kelompok pengrajin tentunya akan berpengaruh terhadap aktivitas klaster yang berlangsung. Oleh karena itu, modal sosial dianggap menjadi suatu variabel penting dalam meningkatkan produktivitas dan perkembangan kelompok industri. Modal sosial secara sederhana digambarkan sebagai hubungan antarindividu, kelompok atau komunitas untuk melakukan aksi-aksi dan kontrol kebersamaan (Bourdieu, 1986). Selanjutnya, definisi modal sosial dikembangkan menjadi 
sebuah struktur sosial yang berfungsi sebagai fasilitator kemanusiaan untuk saling berinteraksi (Coleman, 1988). Melalui definisi tersebut, modal sosial dapat diartikan sebagai modal yang dimiliki oleh masing-masing individu untuk berinteraksi di kehidupan sosialnya.

Putnam (1993) menyebutkan komponen yang terkandung dalam modal sosial meliputi kepercayaan, norma, dan jejaring. Pertama, kepercayaan (trust) tumbuh dalam diri masyarakat karena adanya kejujuran dan sifat menghargai satu sama lain. Shi, Shepherd, dan Schmidts (1999) menemukan penelitian tentang peran kepercayaan dalam usaha yang diterapkan di bisnis keluarga Cina. Pada penelitian tersebut diketahui bahwa ikatan usaha yang terjadi antarkeluarga lebih kuat dibandingkan dengan mitra atau pelaku usaha nonkeluarga. Hal ini dikarenakan keluarga Cina lebih mempercayai dan mengandalkan keluarga dibandingkan membuka peluang bagi tenaga kerja baru. Kedua, norma (norms) tumbuh karena adanya kebersamaan berupa aturan dan kesepakatan baik tertulis maupun tidak tertulis, untuk mengatur jalannya manajemen kelompok industri. Ketiga, jejaring (network) merupakan komponen terpenting untuk menggambarkan model hubungan para pelaku usaha dalam sebuah kelompok industri. Rutten \& Boekema (2007) membuktikan dalam penelitiannya bahwa selain mampu meningkatkan produktivitas, jejaring mampu membentuk inovasi dari masing-masing pelaku usaha.

Peran modal sosial dalam kelompok industri sangat beragam. Nurami (2013) menyebutkan bahwa dengan adanya modal sosial maka akan meningkatkan pemberdayaan masyarakat, sehingga mampu membuka peluang-peluang usaha baru. Modal sosial yang tumbuh dari dalam pelaku usaha industri atau masyarakat yang kemudian membantuk sebuah budaya dan kreativitas (Chuluunbaatar, Luh, \& Kung, 2014). Kreativitas yang tinggi akan membentuk sebuah entrepreneurial orientation dalam pembentukan rantai nilai di dalam aktivitas industri (García-villaverde, Ruiz-ortega, Rodrigo-alarc, \& Parra-requena, 2017). Melalui kreativitas yang dikembangkan juga membuka peluang munculnya inovasi-inovasi dari sebuah kelompok industri yang bernilai tinggi dengan ciri khas lokal (Granovetter \& Ferrary, 2009).

Penelitian ini mengungkap bahwa perkembangan suatu sektor industri, terutama IKM tidak selalu terfokus pada lokasi masing-masing pelaku usaha yang tergabung. Adanya organisasi atau kelompok pengrajin batik yang di dalamnya memiliki modal sosial, akan meningkatkan kebersamaan, keterikatan, yang berakhir pada pemberdayaan dalam industri itu sendiri. Modal sosial yang kuat akan menyatukan pelaku usaha yang secara geografis tersebar menjadi terhubung dalam sebuah interaksi dan komunikasi.

\section{METODE PENELITIAN}

Unit data yang digunakan dalam penelitian ini berjumlah 31 anggota dari kelompok pengrajin batik di Kota Semarang. Pemilihan kelompok pengrajin batik di Kota Semarang ini berdasarkan kebijakan Pemerintah Daerah dalam menerapkan konsep klaster industri. Adanya kelompok atau orgnaisasi ini mampu mewakili pemberdayaan yang terbentuk di antara para pengrajin batik di Kota Semarang. Meskipun Kota Semarang memiliki Kampung Batik yang sangat legendaris, kampung tersebut tidak mampu menggambarkan modal sosial yang terbentuk karena sedikitnya jumlah pengrajin dan tingginya persaingan yang terjadi. Metode yang digunakan dalam penelitian adalah sequential mix method dengan langkah awal mengumpulkan data kuantitatif dan mempertajam hasil analisis kuantitatif dengan data kualitatif. Data kuantitatif penelitian ini berupa tingkat kepercayaan dan tingkat keterhubungan (jejaring) dari masing-masing pengrajin. Tingkat kepercayaan diperoleh melalui penilaian (skor) yang diberikan kepada beberapa pihak terkait yang memiliki kontribusi dalam pengembangan usaha, sedangkan tingkat keterhubungan ini menggambarkan kepada siapa salah seorang pengrajin bekerja sama atau menggantungkan usahanya dalam kelompok pengrajin batik. Selanjutnya, hasil dari data dan analisis kuantitatif tersebut dipertajam dengan data kualitatif melalui indepth interview untuk menggambarkan bagaimana karakteristik ketiga komponen modal sosial dalam kelompok 
pengrajin batik di Kota Semarang. Data kualitatif ini juga berfungsi sebagai bentuk mengkonfirmasi kembali data kuantitatif yang diperoleh.

\section{HASIL DAN PEMBAHASAN}

\section{Trusts (Kepercayaan)}

Kepercayaan dalam penelitian ini menggambarkan bagaimana pengrajin memiliki rasa percaya terhadap pihak-pihak lain yang mempengaruhi usahanya. Rasa saling percaya dapat muncul di antara pengrajin dengan keluarga, pengrajin dengan tetangga, pengrajin dengan pemerintah atau lembaga, bahkan pengrajin dengan sesama pengrajin. Tingkat kepercayaan pengrajin kepada setiap pihak tentunya berbeda, hal ini dipengaruhi oleh beberapa faktor seperti kedekatan lokasi, frekuensi keterlibatan, atau kualitas peran dari masing-masing pihak. Jika dikaitkan dengan frekuensi, kualitas, dan tingkat efektifitas kedekatan para anggota kelompok dengan pihak-pihak terkait akan diperoleh hubungan yang sebanding dengan tingkat kepercayaannya seperti yang digambarkan pada Gambar 1.

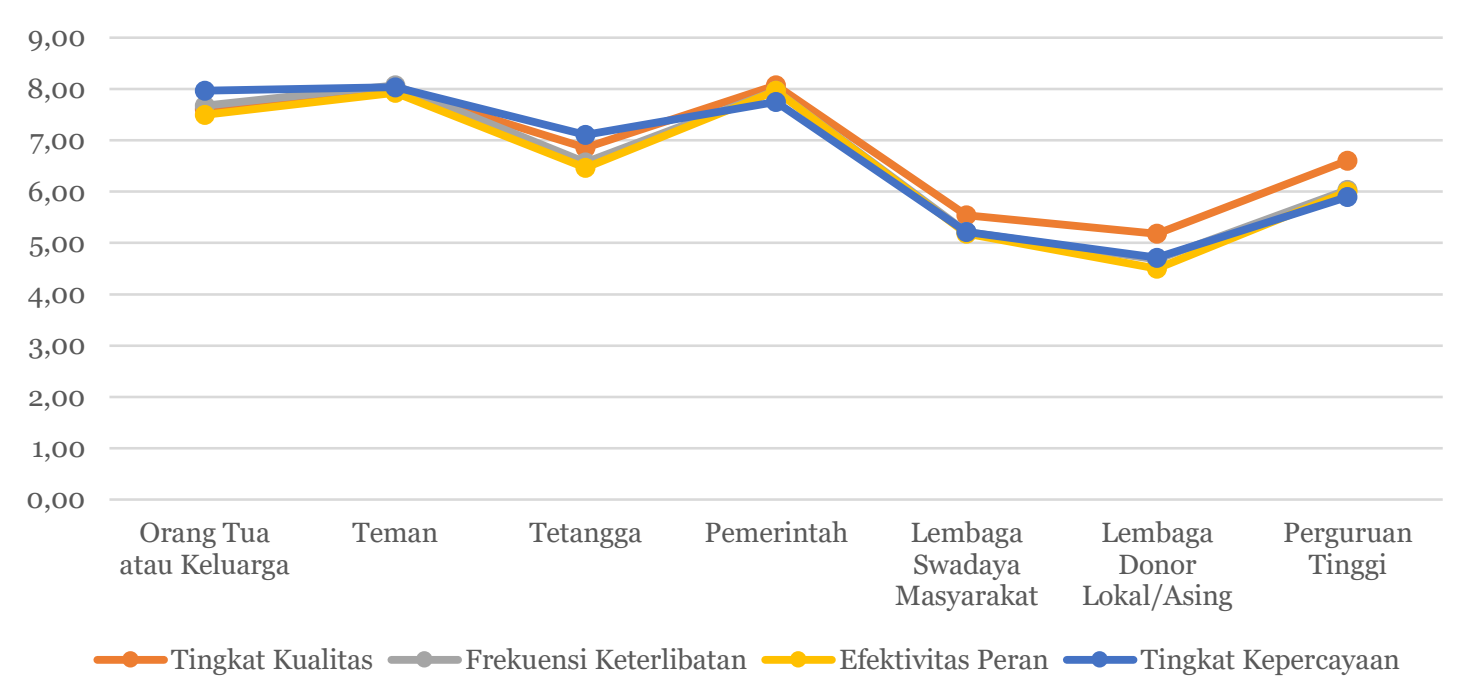

Sumber: Hasil analisis penelitian, 2017

Gambar 1. Hubungan Frekuensi Kedekatan, Kualitas Peran, dengan Efektivitas

Dari survei tersebut diketahui bahwa banyak anggota kelompok yang memberikan tingkat kepercayaan tertinggi kepada teman, baik yang berasal dari dalam maupun luar anggota kelompok. Bagi mereka, teman yang berasal dari anggota kelompok sangat dipercaya karena saling mendukung dan membantu usaha mereka masing-masing. Sesama anggota kelompok saling percaya karena mereka saling menyebarkan informasi terkait pelatihan dan pameran. Sehingga, antarpengrajin tidak saling curiga adanya kecurangan atau hal-hal yang merugikan usahanya masing-masing.

Bagi beberapa pengrajin, tingkat kepercayaan ke setiap anggota kelompok pun berbeda-beda. Ada yang membentuk kelompok kecil dalam mengembangkan usahanya dengan rasa percaya yang lebih tinggi dibandingkan anggota kelompok lainnya. Berdasarkan kondisi lapangan, ditemui dua kelompok kecil yang bernama "SINOM" dan "Mbok Enem". Kelompok "Sinom" terdiri atas 10 anggota kelompok yang berbeda dengan kelompok "Mbok Enem" yang hanya berjumlah 6 orang. Rasa kepercayaan yang dimiliki oleh anggota kelompok-kelompok kecil ini berpengaruh pada jalannya usaha bersama. Karena rasa percaya yang tinggi, biasanya pengrajin A yang tergabung dalam kelompok "Sinom" atau 
"Mbok Enem" akan lebih sering bekerja sama dengan temannya yang sesama anggota kelompok kecil tersebut. Bentuk kerja sama yang terjadi ditunjukkan dengan adanya kebersamaan dalam membeli bahan baku, atau saling supply bahan baku, saling kerja sama produksi, saling titip barang, dan lain sebaganya. Mereka akan lebih nyaman dan percaya untuk bekerja sama dalam kelompok kecil tersebut dibandingkan dengan anggota kelompok lain yang tidak merupakan anggota kelompok kecil mereka. Namun, kepercayaan yang terlalu tinggi juga dapat menghambat perkembangan usaha para anggota kelompok itu sendiri karena membatasi inovasi yang terbentuk. Kepercayaan para pengrajin terhadap pengrajin lainnya dapat berakibat munculnya rasa malas untuk menggali informasi dan mengolahnya secara mandiri karena sudah sangat bergantung dengan pengrajin yang lain.

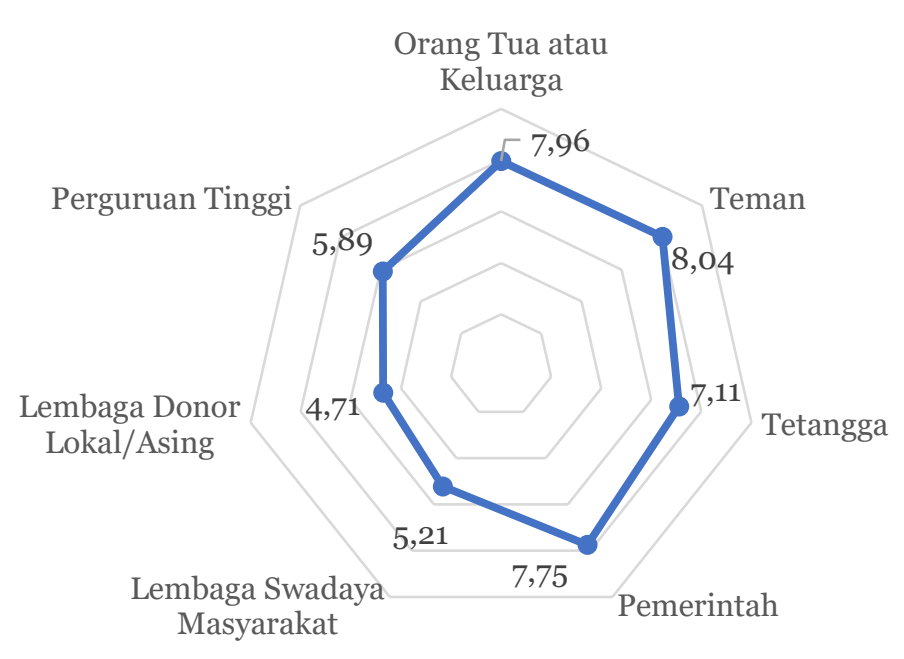

Sumber: Hasil analisis penelitian, 2017

Gambar 2. Tingkat Kepercayaan Pengrajin terhadap Pihak Terkait

\section{a. Norms (Norma)}

Norma dapat berupa aturan tertulis dan tidak tertulis. Norma tertulis dapat berupa norma hukum untuk mengatur manajemen organisasi kelompok pengrajin batik di Kota Semarang. Saat ini, badan hukum kelompok pengrajin batik Kota Semarang dinaungi oleh FEDEP (Forum Economic Development and Employment Promotion), bagian dari BAPPEDA (Badan Perencanaan Pembangunan Daerah) Kota Semarang melalui Surat Keputusan Nomor 050-1334 oleh Pemerintah Kota Semarang. Syarat keanggotaan dari organisasi ini adalah harus merupakan produsen atau pengrajin batik. Sementara itu, untuk struktur kepengurusan organisasi terdiri atas ketua, wakil ketua, bendahara, sekretaris, Pokja SDM (Sumber Daya Manusia), Pokja Humas (Hubungan Masyarakat), Pokja pameran, Pokja permodalan, serta Pokja sosial dan rohani yang aktif selama dua tahun dalam sekali periode kepengurusan.

Norma sosial yang sifatnya tidak tertulis yaitu kesepakatan dalam meningkatkan rasa kebersamaan dan kekeluargaan melalui kegiatan rutin seperti pertemuan/rapat dan iuran. Kebersamaan dan kekeluargaan yang dimaksud tidak hanya saat bertemu ketika menghadiri pertemuan. Sesuai yang dijelaskan sebelumnya bahwa terdapat kesepakatan untuk membayar sejumlah iuran rutin setiap sebulan sekali. Iuran ini selain untuk menjalankan kegiatan manajemen klaster, juga digunakan untuk dana sosial. Apabila terdapat anggota kelompok pengrajin yang sakit, keluarganya meninggal dunia, atau tertimpa musibah lainnya maka akan dibantu dengan menggunakan dana sosial yang berasal dari iuran 
tersebut. Begitulah rasa kebersamaan dan kekeluargaan yang terbentuk. Jadi, tidak hanya bersama sebagai anggota di dalam organisasi yang sama tetapi juga memiliki rasa kepedulian ketika anggota lain mengalami kesulitan.

Keberadaan norma ini berbanding lurus dengan rasa percaya yang diberikan oleh masing-masing anggota klaster. Semakin percaya, maka kebersamaan dan kekeluargaan juga semakin erat. Adanya norma sosial ini akan membentuk lingkungan organisasi kelompok yang kondusif dalam menjalankan manajemen kegiatan. Namun, dampak negatif yang didapatkan dari kuatnya rasa kebersamaan dan kekeluargaan ini memungkinkan adanya ketergantungan yang tinggi, sehingga menghambat perkembangan usaha salah satu pihak.

\section{b. Networks (Jejaring)}

Unsur ketiga yang terkandung dalam modal sosial adalah network atau jejaring. Jejaring ini muncul karena adanya interaksi antarindividu. 31 dari 39 pengrajin yang masih aktif menjadi anggota kelompok memiliki jejaring terkuat dengan sesama anggota kelompok yang lain. Jejaring yang terjadi di internal anggota kelompok ini tentunya akan menghasilkan informasi siapakah yang menjadi local champion atau yang memiliki peran utama dalam berjalannya aktivitas kelompok pengrajin batik Kota Semarang. Di lapangan, masingmasing pengrajin dibebaskan untuk memilih 3 anggota kelompok lainnya yang paling berpengaruh dalam berjalannya usaha batik mereka. Masing-masing pengrajin minimal harus memberikan 2 pilihan yang kemudian dianalisis dengan teknik social network analysis untuk mengetahui bentuk jejaring internal yang terjadi di dalam keanggotaan organisasi kelompok pengrajin batik Kota Semarang. Local champion yang menggambarkan tokoh utama yang paling memiliki peran atau paling digantungkan oleh anggota lainnya dalam keorganisasian kelompok pengrajin batik Kota Semarang. Tiga tokoh utama didapatkan dari hasil pemilihan tiap-tiap anggota kelompok. Untuk mengetahui bentuk jejaring yang terjadi secara internal keorganisasian klaster, digambarkan melalui social network analysis yang memberikan model jejaring yang terbentuk.

Tabel 1. Hasil Perhitungan Social Network Analysis

\begin{tabular}{lllll}
\hline No. & Nama & & Nilai \\
\hline 1 & Joko Sunarto & $40 / 30$ & $=$ & 1,33 \\
2 & Ngatmi & $0 / 30$ & $=$ & 0 \\
3 & Zeela Zalzilah & $38 / 30$ & $=$ & 1,27 \\
4 & Yuspinah & $0 / 30$ & $=$ & 0 \\
5 & Woro Prijaningrum & $0 / 30$ & $=$ & 0 \\
6 & Umi Salamah & $4 / 30$ & $=$ & 0,13 \\
7 & Triningtyas Nurhayati & $0 / 30$ & $=$ & 0 \\
8 & Tri Utomo & $0 / 30$ & $=$ & 0 \\
9 & Siti Khalifah & $5 / 30$ & $=$ & 0,17 \\
10 & Siti Afifah & $11 / 30$ & $=$ & 0,37 \\
11 & Ruth Endang Setyorini & $3 / 30$ & $=$ & 0,1 \\
12 & Rini Sari Handayani & $0 / 30$ & $=$ & 0 \\
13 & Reni Tirana & $0 / 30$ & $=$ & 0 \\
14 & Rahayu Ningsih & $3 / 30$ & $=$ & 0,1 \\
15 & Ning A. Restu & $1 / 30$ & $=$ & 0,03 \\
16 & Liestyowati & $5 / 30$ & $=$ & 0,17 \\
17 & Katarina Niken Utari & $0 / 30$ & $=$ & 0 \\
18 & Hermin Indrayanti & $0 / 30$ & $=$ & 0 \\
19 & Eva Daryuni & $0 / 30$ & $=$ & 0 \\
20 & Ester Ribut Sunarmi & $3 / 30$ & $=$ & 0,1 \\
21 & Erna Setyawati & $1 / 30$ & $=$ & 0,03 \\
22 & Eny Farida & $0 / 30$ & $=$ & 0 \\
23 & Endang Purwati & $6 / 30$ & $=$ & 0,2 \\
\hline
\end{tabular}




\begin{tabular}{cllll}
\hline No. & Nama & & Nilai \\
\hline 24 & Elly Noeryani & $2 / 30$ & $=$ & 0,07 \\
25 & Elisabeth Algonda & $1 / 30$ & $=$ & 0,03 \\
26 & Dyah Kumala Sari & $0 / 30$ & $=$ & 0 \\
27 & Ari Kristyowati & $2 / 30$ & $=$ & 0,07 \\
28 & Aenin & $0 / 30$ & $=$ & 0 \\
29 & Nofianah & $41 / 30$ & $=$ & 1,37 \\
30 & Eko Hariyanto & $8 / 30$ & $=$ & 0,27 \\
31 & Rena Dyah Luminarti & $9 / 30$ & $=$ & 0,3 \\
Sumber: Hasil analisis penelitian, 2017 & & &
\end{tabular}

Pada Gambar 2 merupakan ilustrasi dari hasil perhitungan sebelumnya. Lingkaranlingkaran yang terdapat pada gambar, mengilustrasikan orde atau orbit. Semakin dalam posisi seseorang atau pengrajin, maka pengrajin tersebut semakin berperan. Begitu pula kebalikannya, semakin luar semakin tidak berperan apa-apa di dalam keanggotaan klaster. Dari gambar tersebut dapat dibagi menjadi 3 orbit. Masing-masing orbit diduduki oleh beberapa anggota kelompok dengan penjelasan sebagai berikut:

1. Orbit 1 , merupakan orbit terdalam dan menjadi tokoh yang mendominasi peran di dalam keanggotaan klaster batik Semarang. Biasanya anggota kelompok yang termasuk dalam orbit terdalam paling dijdikan tempat bergantung dari segala hal oleh para anggota kelompok. Pada orbit ini terdiri atas Bu Nofianah yang merupakan ketua kelompok pengrajin tahun 2013 - 2015 dan wakil ketua kelompok pada tahun 2015-2017. Kemudian Pak Joko Sunarto yang merupakan ketua kelompok pengrajin tahun 2015 - 2017, serta Bu Zeela Zalzilah yang merupakan inisiator dalam memberikan pengetahuan dan pelatihan kepada pengrajin batik di Kota Semarang.

2. Orbit 2, merupakan anggota kelompok yang sedang-sedang saja. Anggota kelompok ini dikatakan cukup lama bergabung di klaster batik Semarang dan sudah memiliki jejaring untuk bekerja sama. Pada orbit 2 ini terdiri atas Bu Siti Kholifah, Pak Eko Hariyanto, Bu Rena Dyah Luminarti, Bu Ruth Endang Setyorini, Bu Liestyowati, Bu Rahayu Ningsih, dan Bu Siti Afifa. Orbit ini sempat memberikan peran yang cukup banyak di masa lampau. Seperti halnya Bu Siti Kholifah yang menjadi ketua kelompok selama dua periode pada tahun 2009 - 2013, Pak Eko Hariyanto yang merupakan pengrajin awal dan menjadi ketua paguyuban di Kampung Batik Bubakan, serta beberapa pengrajin lain yang memiliki banyak pengetahuan terhadap perkembangan batik di Kota Semarang.

3. Orbit 3, merupakan anggota kelompok yang rata-rata baru bergabung atau memiliki tingkat yang rendah bila dilihat dari produktivitas dan keaktifannya sebagai anggota kelompok. Orbit 3 terdiri atas anggota-anggota lain yang tidak termasuk ke dalam orbit 1 dan orbit 2.

Melalui trust (kepercayaan), norms (norma), dan network (jejaring) hubungan modal sosial yang terjadi di dalam keanggotaan klaster batik Semarang tergolong baik, namun tetap harus ditingkatkan. Terutama dalam meningkatkan rasa kebersamaan dan kekeluargaan yang mencegah terjadinya persaingan dan konflik. Selain itu, pertemuan rutin harus segera dijadwalkan rutin sebagai salah satu cara untuk mengakrabkan kembali anggota kelompok pengrajin batik di Kota Semarang. Terjaganya modal sosial yang dimiliki oleh keanggotaan kelompok pengrajin batik Kota Semarang juga akan membawa banyak keuntungan baik bagi usaha individu maupun kemajuan klaster itu sendiri.

Karakteristik modal sosial yang terbentuk di keanggotaan kelompok pengrajin batik Semarang termasuk ke dalam tipologi bridging dan linking. Hal ini dikarenakan masingmasing pengrajin saling dipertemukan dalam sebuah kegiatan pelatihan atau pameran, bukan karena faktor generasi kekeluargaan maupun kedekatan lokasi tempat tinggal. Bridging social capital juga digambarkan oleh keanggotaan klaster karena pengrajin ini 
memiliki modal sosial karena termasuk ke dalam organisasi yang sama. Hal ini menyebabkan mereka memiliki rasa saling mempercayai, terdapat nilai dan norma yang mengatur segala perilaku dan aktivitas, serta membentuk jejaring. Lingking social capital digambarkan dengan adanya jejaring yang terbentuk antara para anggota kelompok dengan pihak-pihak terkait lainnya seperti pemerintah, perguruan tinggi, dan lembaga-lembaga lainnya.

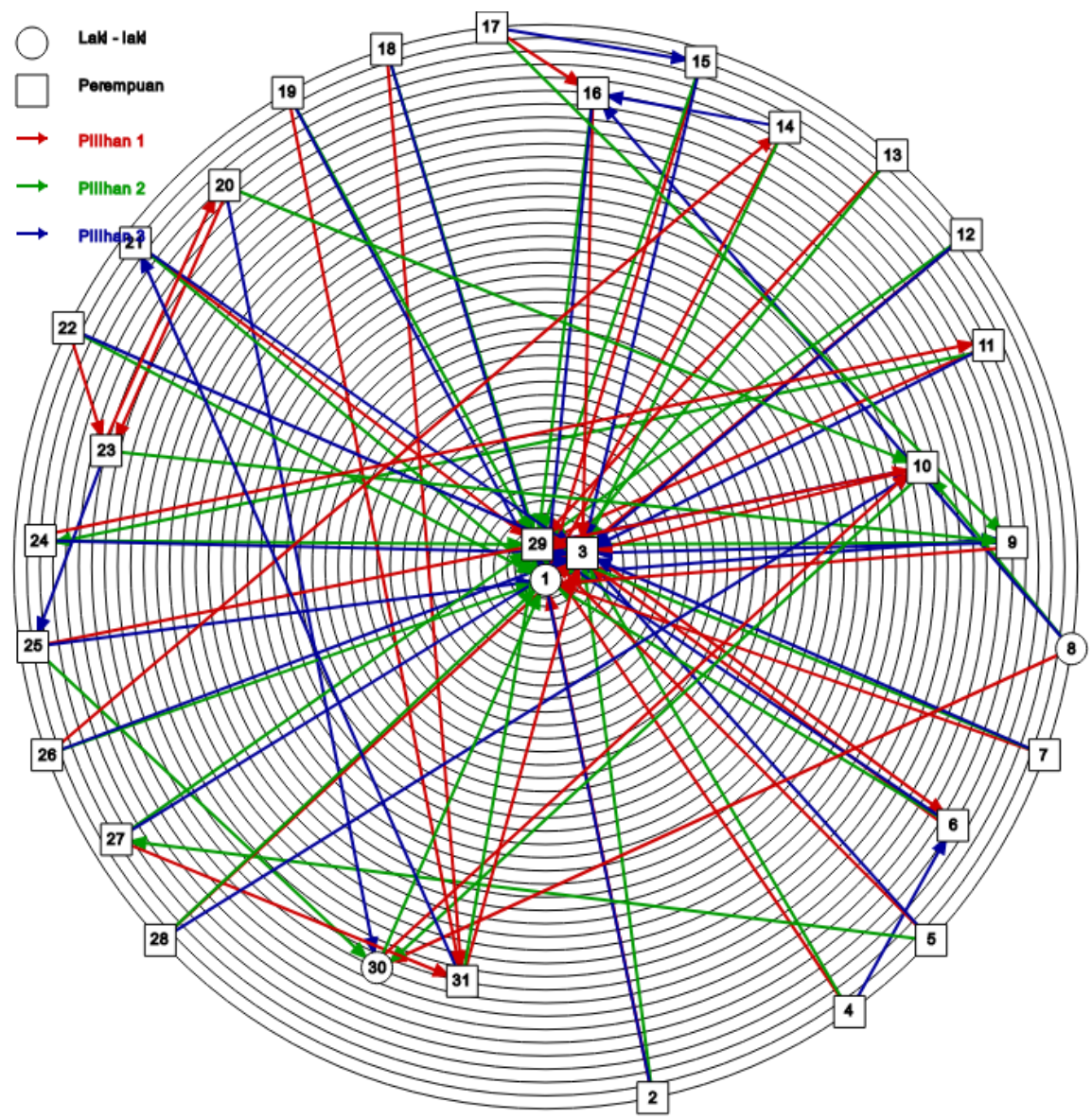

Sumber: Hasil analisis penelitian, 2017

Gambar 2. Social Netwok Analysis dari Keanggotaan Kelompok Pengrajin Batik Kota Semarang

Modal sosial yang terdapat pada keanggotaan kelompok pengrajin batik Kota Semarang juga membentuk beberapa tipe hubungan antara lain kerja sama dan persaingan. Kerja sama yang terjadi antarpengrajin sebagai anggota kelompok ditunjukkan dengan adanya kerja sama proses produksi dan "nitip dagang". Khususnya, bagi mereka yang tergabung dalam kelompok-kelompok kecil "Sinom" dan "Mbok Enem". Kelompok kecil tersebut bersama-sama pergi ke Pekalongan atau Surakarta untuk membeli bahan baku. Apabila jumlah bahan baku yang dibutuhkan hanya sedikit, pengrajin dapat menitipkannya kepada anggota kelompok yang lain. Dalam proses produksi kerja sama juga dapat dilihat melalui pembagian kerja, yang mana ada anggota kelompok yang hanya mendesain dan mencanting kemudian pewarnaan dilakukan oleh anggota kelompok yang lain. Hal ini tentunya mempermudah pelaksanaan proses produksi. Kemudian, kerja sama juga terjadi pada saat pemasaran produk dengan "nitip dagang" pada saat pameran. Di sisi lain, keanggotaan kelompok juga memiliki persaingan yang digambarkan oleh penjualan masing- 
masing produk dengan cara masing-masing. Hal ini terjadi ketika tidak ada pameran yang sedang dilaksanakan, sehingga produk dijual sendiri baik melalui gerai pribadi maupun cara lainnya.

\section{KESIMPULAN}

Terdapat prinsip umum dari konsep klaster yang mengartikan bahwa klaster merupakan sekumpulan usaha yang memiliki commonality (kesamaan), concentration (terkonsentrasi), dan connectivity (terkoneksi). Meskipun kelompok pengrajin batik Kota Semarang saat ini tidak memiliki unsur concentration (terkonsentrasi) pada suatu lokasi, tidak membatasi para pengrajin untuk membentuk kerja sama dalam aktivitas kelompok pengrajin batik. Hal ini dikarenakan adanya modal sosial yang kuat antarpengrajin di dalam keorganisasian tersebut. Modal sosial terdiri atas 3 unsur utama, yaitu trust (kepercayaan), norms (norma), dan networks (jejaring) yang terdapat di dalam keorganisasian kelompok sehingga membentuk suatu jejaring kerja sama.

Kepercayaan merupakan salah satu unsur penting dalam modal sosial karena berperan sebagai "katalisator" dalam membentuk jejaring dan norma. Kepercayaan yang dimiliki oleh masing-masing anggota kelompok terhadap pihak-pihak terkait memiliki tingkat yang berbeda-beda. Berdasarkan hasil survei diketahui bahwa rasa percaya berbanding lurus dengan tingkat frekuensi kedekatan dan kualitas peran dari masing-masing pihak terhadap perkembangan usaha. Rasa kepercayaan para anggota kelompok tertinggi ditujukan kepada teman sesama anggota kelompok, kemudian diikuti dengan Pemerintah dan orang tua atau keluarga. Kepercayaan yang tinggi kepada sesama anggota kelompok ini menunjukkan bahwa di dalam organisasi kelompok terdapat interaksi dan jejaring yang kuat sehingga muncul norma kekeluargaan di dalamnya. Norma kekeluargaan menjadi prinsip utama di dalam keanggotaan kelompok. Kerja sama yang terbentuk akibat adanya jejaring yang kuat di dalam organisasi kelompok dapat digambarkan dalam aktivitas produksinya baik dari proses produksi hingga pemasaran. Kerja sama produksi dilakukan ketika membeli bahan baku hingga proses produksinya. Sedangkan kerja sama pemasaran dilakukan melalui "nitip dagang" ketika pameran berlangsung. Dengan adanya kerja sama di dalam aktivitas produksi tersebut dapat diperoleh beberapa manfaat antara lain rendahnya biaya transportasi untuk bahan baku, waktu produksi lebih singkat, dan luasnya pangsa pasar yang diperoleh.

Berdasarkan mekanisme modal sosial yang terbentuk di dalam organisasi kelompok, dapat diperoleh kesimpulan bahwa peran modal sosial dalam perkembangan kelompok adalah meningkatnya pemberdayaan masyarakat melalui tingginya partisipasi yang terbentuk; kuatnya organisasi karena adanya modal sosial yang mengikat antara satu anggota dengan lainnya; meningkatnya kreativitas berwirausaha melalui diadakannya pelatihan-pelatihan sehingga membentuk industri yang kreatif; membentuk efektivitas pengelolaan sumberdaya melalui kerja sama yang dilakukan dalam aktivitas produksi; serta meningkatkan produktivitas dan daya saing industri melalui kerja sama pemasaran yang terbentuk saat pameran berlangsung

\section{DAFTAR PUSTAKA}

Bourdieu, P. (1986). The forms of capital. Handbook of Theory and Research for the Sociology of Education, 241-258. https://doi.org/10.1002/9780470755679.ch15

Chuluunbaatar, E., Luh, D., \& Kung, S. (2014). The Role of Cluster and Social Capital in Cultural and Creative Industries Development. Procedia - Social and Behavioral Sciences, 109, 552-557. https://doi.org/10.1016/j.sbspro.2013.12.506

Coleman, J. S. (1988). Social Capital in the Creation of Human Capital, 78(6), 1360-1380. https://doi.org/10.1037/0012-1649.22.6.723

Cresswell, J. W. (2014). Research Design. Qualitative, Quantitative and Mixed methods approaches. Research Design Qualitative Quantitative and Mixed Methods Approaches. Sage Publications. https://doi.org/10.1007/s13398-014-0173-7.2 
Djamhari, C. (2006). Faktor-Faktor Yang Mempengaruhi Perkembangan Sentra UKM Menjadi Klaster Dinamis. Infokop, (29 Tahun XXII), 83-91.

García-villaverde, P. M., Ruiz-ortega, M. J., Rodrigo-alarc, J., \& Parra-requena, G. (2017). From social capital to entrepreneurial orientation: The mediating role of dynamic capabilities. https://doi.org/10.1016/j.emj.2017.02.006

Granovetter, M., \& Ferrary, M. (2009). The role of venture capital firms in Silicon Valley' s complex innovation network, (906870037). https://doi.org/10.1080/03085140902786827

Lyon, F., \& Atherton, A. (2000). A business view of clustering: Lessons for cluster development policies. Foundation for SME Development, University of Durham, 1-13. Retrieved from http://scholar.google.com/scholar?hl=en\&btnG=Search\&q=intitle:A+business+view+of+clustering+: + Lessons+for+cluster+development+policies\#4

Marshall, A. (1920). Industry and Trade. Journal of the Royal Statistical Society, 83, 292. https://doi.org/10.2307/2341084

Nurami, M. (2013). Peran Modal Sosial pada Pemberdayaan Ekonomi Masyarakat (Studi pada Usaha Daur Ulang di Desa Kedungwonokerto, Kecamatan Prambon, Sidoarjo).

Porter, M. E. (1985). Competitive Advantage - Creating and Sustaining Superior Performance. New York: FreePress. https://doi.org/10.1182/blood-2005-11-4354

Putnam, R. D. (1993). What markes democrcy work? National Civic Review, 82, 101-107. https://doi.org/10.1002/ncr.4100820204

Rutten, R., \& Boekema, F. (2007). Regional social capital: Embeddedness, innovation networks and regional economic development. Technological Forecasting and Social Change, 74(9), 1834-1846. https://doi.org/10.1016/j.techfore.2007.05.012

Shi, H. X., Shepherd, D. M., \& Schmidts, T. (1999). Social Capital in Entrepreneurial Family Businesses: The Role of Trust. Int J Logistics Management. https://doi.org/10.1108/09574090910954864 